\title{
Ambisi Tokoh Uchiha Itachi Dalam Anime Naruto Shippuden Karya Masashi Kishimoto
}

\author{
Aisyah Shabrina*, Yusida Lusiana, Yudi Suryadi \\ Program Studi Sastra Jepang, Universitas Jenderal Soedirman, Purwokerto, Indonesia \\ email: aisyahsbn10@gmail.com*
}

DOI: 10.20884/1.jlitera.2020.2.1.3144

\begin{abstract}
This research discusses about characterization and ambition of Uchiha Itachi of Naruto Shippuuden's Anime By Masashi Kishimoto. The purpose of this research is to describe the characterization and ambition of Uchiha Itachi. Uchiha Itachi appears to maintain Konoha's Village peaceful as a trigger for conflict and help resolve of Naruto Shippuuden's storyline. The research will use qualitative descriptive method, observe and record method and the characterization theory by Nurgiyantoro and ambition theory by Widarso. The data source of this research are twelve episodes of Naruto Shippuuden's Anime By Masashi Kishimoto that appearing Uchiha Itachi character as a triggers the conflicst and helps resolve of Naruto Shippuuden's storyline eventhought it was not the main character. The result of this research is to describe the Uchiha Itachi's character and his ambition that effected by several factor and foul ambition.
\end{abstract}

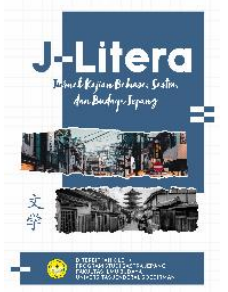

Keywords:

Ambition; Uchiha itachi;

Naruto shippuden; Masashi

kishimoto

Article Info:

First received:

13 August 2020

Available online:

30 November 2020

\section{PENDAHULUAN}

Karya sastra umumnya dibagi menjadi puisi, cerpen, novel, dan drama. Seiring perkembangan zaman, karya sastra juga berkembang ke bentuk lain yang lebih modern seperti film dan film animasi. Seperti halnya dengan karya sastra naratif lainnya seperti cerpen dan novel, film juga memiliki unsurunsur yang membangun karya sastra itu sendiri. Unsur yang dimaksud disini adalah unsur intrinsik dan ekstrinsik (Susanti, 2017: 319).

Adapun pengertian unsur intrinsik dari Nurgiyantoro adalah unsur-unsur yang membangun karya sastra itu sendiri. Unsurunsur inilah yang menyebabkan karya sastra hadir sebagai karya sastra, unsur-unsur yang secara faktual akan dijumpai jika orang membaca karya sastra. (Nurgiyantoro, 2002 : 23). Lebih lanjut Nurgiyantoro mengemukakan unsur intrinsik sebuah drama adalah unsurunsur yang (secara langsung) turut serta membangun cerita. Kemudian pada novel unsur intrinsik itu berupa, tema, plot, perwatakan, latar, sudut pandang, gaya bahasa, dan amanat Nurgiyantoro (2007:23). Dapat diselaraskan bahwa unsur intrinsik merupakan unsur-unsur yang membangun karya sastra yang berupa tema, plot, perwatakan, latar, sudut pandang, gaya bahasa, dan amanat.

Unsur karya sastra selanjutnnya, unsur ektrinsik adalah unsur yang berada di luar karya sastra atau cerita, namun turut menentukan bentuk dan isi suatu karya atau cerita. Unsur ekstrinsik meliputi agama, politik, sejarah, budaya. (Aminuddin, 2004:85). Unsur ini hampir sama dengan unsur amanat yang ada dalam unsur intrinsik. yaitu memberikan pengetahuan dan pemahaman akan sesuatu terhadap pengamat melalui kandungan nilainilai yang tersemat dalam sebuah karya sastra tersebut. nilainilai yang ada dalam unsur ekstrinsik berpengaruh tidak nyata, namun dapat di rasakan ada keberadaarmya dengan sebuah pemahaman yang mendalam akan sebuah karya sastra dengan memahami secara mendalam arti kandungan sebuah karya sastra, kita dapat menganaiisis nilai-nilai apa saja dan amanat apa saja yang ada di dalam karya sastra tersebut. 
Sama dengan karya sastra lain animasi juga memiliki narasi penyerta gambar. Narasi yang muncul terkadang berupa onomatopea suara binatang, bunyi benda jatuh, desiran angin, dan sebagainya. Berkaitan dengan teks narasi (narrative text) tentu akan menyentuh bidang kesusastraan (Sobur, 2004:136). Pernyataan lain Alex Sobur yang mendukung bahwa anime tak lepas dari bidang sastra yaitu bahwa elemen pembentuk komik-kartun cukup kompleks, yakni terdiri atas unsur-unsur berbagai disiplin, misalnya bidang seni rupa, sastra, linguistik, dan sebagainya.

Serial anime Naruto Shippuden diadaptasi dari manga atau komik Jepang, dengan judul Naruto karya Masashi Kishimoto. Pada awalnya manga Naruto diadaptasi ke dalam anime dengan judul yang sama, kemudian pada ketika tokoh utama, Naruto tumbuh dewasa serial animenya berubah judul menjadi Naruto Shippuden. Meskipun ada sedikit penambahan cerita dalam serial anime-nya, ide cerita Masashi Kishimoto tetap utuh dalam adaptasi tersebut.

Anime Naruto menceritakan tokoh utamanya, Naruto Uzumaki, seorang ninja yang ingin mewujudkan keinginannya untuk menjadi Hokage (pemimpin dan ninja terkuat di desanya.) Serial Naruto dilanjutkan dengan Naruto Shippuden. Naruto Shippuden menceritakan Naruto yang memiliki tujuan utama yaitu mencari Uchiha Sasuke yang sebelumnya merupakan teman satu tim Naruto, sementara Sasuke bertujuan untuk mencari kakak kandungnya yang bernama Uchiha Itachi untuk membalaskan dendam karena telah membunuh seluruh anggota klan Uchiha dan bergabung dalam kelompok bernama Akatsuki yang memiliki tujuan membangkitkan suatu kekuatan besar dan diiringi oleh perang dunia. Setelah mendengar kebenaran tentang desa dan klan Uchiha, dan alasan semua tindakan kakaknya, akhirnya Sasuke memutuskan membantu mengakhiri perang. Setelah perang selesai, Naruto berhasil meyakinkan Sasuke untuk kembali ke jalan yang benar lewat pertarungan mereka.

Uchiha Itachi merupakan kakak kandung dari Uchiha Sasuke, teman satu tim Naruto di akademi tempatnya belajar. Uchiha Itachi berasal dari dari klan Uchiha. Ia bertanggung jawab atas peristiwa pembantaian klan Uchiha yang telah membuatnya menjadi seorang ninja buronan. Awalnya Itachi tumbuh menjadi sebuah kebanggaan bagi klannya, karena kemampuannya yang begitu luar biasa. Setelah terjadi suatu konflik antara desa dan Klan Uchiha, Klan Uchiha memulai rencana kudeta terhadap desa Konoha. Menyadari bahwa kudeta ini hanya akan memicu peperangan antar negara-negara ninja dan membawa banyak pertumpahan darah, Itachi yang sangat mencintai kedamaian menerima misi dan membulatkan tekad untuk membantai seluruh klan Uchiha. Semua yang telah dilakukan Uchiha Itachi demi mempertahankan kedamaian Desa Konoha sesuai dengan keinginannya.

Salah satu keinginan tokoh Uchiha Itachi, ialah mempertahankan kedamaian desa Konoha. Keinginan tersebut sangatlah besar meskipun tokoh tersebut rela melindungi desanya dengan membunuh, dianggap sebagai penghianat dan menjadi buronan dalam sisa hidupnya. Keinginan yang besar ini merupakan ambisi yang akan peneliti analisis. Sesuai dengan definisi seorang psikiatris Austria, Alfred Adler mendefinisikan ambisi sebagai keinginan yang bersifat alamiah untuk mencapai tahap kelengkapan atau pencapaian yang lebih tinggi (Alfred Adler dalam Widarso 1992:11). Peneliti memilih menganalisis ambisi tokoh karena agar memahami banyak tokoh yang memiliki karakter ambisi untuk mengejar keinginan atau pencapaian dalam cerita.

Pada penelitian ini peneliti menfokuskan menganalisis serial anime Naruto Shippuden daripada seri manga-nya. Hal tersebut karena anime menampilkan gambar yang bergerak dan suara yang tidak dapat dirasakan dari manganya. Anime dengan genre action seperti ini kebanyakan hanya dilihat dari sudut pandang tokoh utama yaitu, Uzumaki Naruto. Namun peneliti mencoba meneliti ambisi tokoh Uchiha Itachi dalam anime Naruto Shippuden, yang memiliki karakter yang kuat juga merupakan salah satu tokoh heroik dan memiliki peran yang cukup penting dan tidak dapat diabaikan dalam konflik pada alur cerita, meskipun tokoh Uchiha Itachi bukan tokoh utama dalam anime tersebut.

Pada penelitian ini peneliti mencoba menganalisis ambisi tokoh Uchiha Itachi dalam serial anime Naruto Shippuden karya Masashi Koshimoto. Penelitian ini merupakan salah satu cara untuk memahami tokoh dalam anime tersebut. Dalam penelitian ini, penulis menggunakan teori oleh Nurgiyantoro yaitu 
unsur intrinsik penokohan, teori ambisi oleh Widarso.

\section{TINJAUAN PUSTAKA}

\section{Penokohan}

Penokohan adalah salah satu unsur intrinsik dalam teori struktural. Penokohan sebagai salah satu unsur pembangun fiksi dapat dikaji dan dianalisis keterjalinannya dengan unsur-unsur pembangun lainnya. Jika fiksi yang bersangkutan merupakan sebuah karya sastra yang berhasil, penokohan pasti berjalan secara harmonis dan saling melengkapi dengan berbagai unsur yang lain, misalnya dengan unsur plot dan tema, atau, unsur latar, sudut pandang, gaya, amanat, dan lain-lain seperti yang diungkapkan Nurgiyantoro (2013: 254).

Mengenal penokohan dapat dibagi menjadi beberapa dimensi seperti yang diungkapkan Waluyo (2003: 14-19) penokohan yang digambarkan dalam tiga dimensi (watak dimensional). Penggambaran itu berdasarkan keadaan fisik (fisiologis), psikis (psikologis), dan sosial (sosiologis).

Dimensi penokohan yang pertama ialah keadaan fisik, yang termasuk dalam keadaan fisik tokoh adalah umur, jenis kelamin, ciri-ciri khas yang menonjol, suku bangsa, raut muka, kesukaan, tinggi/pendek, kurus/gemuk, dan sebagainya. Kemudian, dimensi penokohan kedua keadaan psikis, yang termasuk dalam keadaan psikis tokoh adalah keagamaan, mentalitas, standar moral, temperamen, ambisi, kompleks psikologis yang dialami, keadaan emosinya, dan sebagainya. Dimensi penokohan yang terakhir ialah keadaan sosiologis, yang termasuk dalam keadaan sosiologis tokoh adalah jabatan, pekerjaan, kelas sosial, ras, agama, dan sebagainya.

Ketiga dimensi ini biasanya sangat berperan dalam menggali karakter tokoh dan sangat memudahkan pembaca sastra dalam mengetahui karakter tokoh. Dengan tiga dimensi tersebut kita dapat mengenali ciri-ciri tubuh tokoh dan sifat kejiwaan tokoh. Selain itu, dapat pulamengetahui sesuatu yang berkaitan dengan aspek sosiologis tokoh.

Untuk menganalisis dimensi penokohan tersebut, terdapat beberapa metode untuk meneliti bagaimana penokohan pada karya sastra seperti dikatakan oleh Minderop (2005: 3), karakterisasi tokoh dapat ditelaah dengan lima metode yakni, metode langsung (telling) dan metode tidak langsung (showing) (Minderop, 2005: 2-50)

\section{a. Metode Langsung (telling)}

Metode ini merupakan pemaparan karakter tokoh yang dilakukan secara langsung oleh pengarang. Metode ini biasanya digunakan oleh kisah-kisah rekaan zaman dahulu sehingga pembaca hanya mengandalkan penjelasan yang dilakukan pengarang semata. Pada metode ini, karakterisasi tokoh dapat melalui penggunaan nama tokoh, penampilan tokoh, dan tuturan pengarang. Penggunaan nama tokoh dugunakan untuk memperjelas dan mempertajam perwatakan tokoh serta melukiskan kualitas karakteristik yang membedakannya dengan tokoh lain.

Suatu karya sastra, penampilan para tokoh memegang peranan penting sehubungan dengan telaah karakterisasi. Penampilan tokoh yang dimaksud misalnya, pakaian apa yang dikenakannya atau bagaimana ekspresinya. Pemberian rincian tentang cara berpakaian memberikan gambaran tentang pekerjaan, status sosial, dan bahkan derajat harga dirinya.

Karakterisasi melalui tuturan pengarang memberikan tempat yang luas dan bebas kepada pengarang atau narator dalam menentukan kisahannya. Pengarang tidak sekadar menggiring perhatian pembaca terhadap komentarnya tentang watak tokoh, tetapi juga mencoba membentuk presepsi pembaca tentang tokoh yang dikisahkannya (Minderop, 2005: 8). Kelemahan dari metode ini adalah sifat mekanismenya yang menciutkan partisipasi imajinatif pembaca, sedangkan kelebihan metode ini terletak pada kesederhanaan dan ekonomisnya (Sayuti, 2000: 90).

Minderop membagi metode karakterisasi ini mencakup: (a) Karakterisasi melalui penggunaan nama tokoh (characterization through the use of names), (b) Karakterisasi melalui penampilan tokoh (characterization through appearance), (c) karakterisasi melalui tuturan pengarang (characterization by the author).

Karakterisasi melalui penggunaan nama tokoh (characterization through the use of names). Nama tokoh dalam suatu karya sastra 
kerap kali digunakan untuk memberikan ide atau menumbuhkan gagasan, memperjelas serta mempertajam perwatakan tokoh. Para tokoh diberikan nama yang melukiskan kualitas karakteristik yang membedakannya dengan tokoh lain. Nama tersebut mengacu pada karakteristik dominan si tokoh. Contohnya, Dayu Cenana (Dayu Cenana memiliki arti kayu cendana, yaitu kayu yang keras dan berbau harum) adalah tokoh yang memiliki perangai dan pendirian yang keras serta memiliki wajah dan penampilan yang menarik (Marliah, 2016: 22-23).

Karakterisasi melalui penampilan tokoh (characterization through appearance). Walaupun dalam kehidupan sehari-hari kita kerap terkecoh oleh penampilan seseorang, bahkan kita dapat tertipu oleh penampilannya, dalam suatu karya sastra, faktor penampilan para tokoh memegang peranan penting sehubungan dengan telaah karakterisasi. Penampilan tokoh yang dimaksud misalnya, pakaian apa yang dikenakannya atau bagaimana ekspresinya.

karakterisasi melalui tuturan pengarang (characterization by the author). Metode karakterisasi ini memberikan tempat yang luas dan bebas kepada pengarang atau narator dalam menentukan kisahannya. Narator berkomentar tentang watak dan kepribadian para tokoh hingga menembus ke dalam pikiran, perasaan dan gejolak batin sang tokoh. Dengan demikian, narator terus menerus mengawasi karakterisasi tokoh. Pengarang yang sekaligus menjadi narator tidak hanya sekadar menggiring perhatian pembaca terhadap komentarnya tentang watak tokoh, tetapi juga mencoba membentuk persepsi pembaca tentang tokoh yang dikisahkannya.

\section{b. Metode Tidak Langsung (showing)}

Metode tidak langsung (showing) merupakan metode yang mengabaikan kehadiran pengarang sehingga para tokoh dalam karya sastra dapat menampikan diri secara langsung melalui tingkah laku mereka. Pada metode ini, karakterisasi dapat mencakup beberapa hal berikut, yaitu (a) karakterisasi melalui dialog (lokasi dan situasi percakapan, jatidiri tokoh yang dituju oleh penutur, kualitas mental para tokoh; nada suara, tekanan, dialek, dan kosa kata) dan (b) karakterisasi melalui tindakan para tokoh. Pembaca harus memperhatikan substansi dari suatu dialog. Apakah dialog tersebut sesuatu yang terlalu penting sehingga dapat mengembangkan peristiwa-peristiwa dalam suatu alur atau sebaliknya.

\section{Ambisi}

\section{Pengertian Ambisi}

Ambisi menurut Kamus Bahasa Indonesia yaitu suatu dorongan psikologis seseorang atau sekelompok orang yang berusaha mencapai tujuan yang lebih baik (2008: 69). Dari definisi tersebut ambisi dapat dimaknai sebagai dorongan atau motivasi seseorang untuk mencapai suatu tujuan yang telah dicitacitakannya. Kata ambisi juga biasanya diartikan sebagai keinginan untuk mencapai tujuan tertentu dengan cara apapun. Menurut Tatenhove (1984: 19), "ambition is an energy, expressed in active behaviors toward some purpose or aspiration". Definisi tersebut dapat diartikan, ambisi adalah energi yang diwujudkan dalam perilaku yang diarahkan ke suatu tujuan atau cita-cita (Tatenhove dalam Widarso, 1992: 11).

Menurut Widarso (1992: 12) tidak terlihat adanya sifat negatif yang terkandung dalam kata ambisi dari makna kata ambisi tersebut. Kecenderungan makna negatif tersebut muncul karena biasanya orang yang berhasrat mencapai kedudukan yang tinggi sering menggunakan berbagai cara, jadi ambisi menjadi buruk jika menempel pada orang yang memiliki sikap mental negatif, misalnya orang yang suka mengeksploitasi orang lain untuk memuaskan kepentingan diri sendiri. Padahal dalam arti denotasinya ambisi tidak bermakna negatif karena dengan cita-cita orang akan menentukan karya yang ingin dicapai, dan kemudian harus berjuang merealisasikannya.

\section{Faktor Pendorong Munculnya Ambisi}

Widarso dalam bukunya Ambisi Kawan atau lawan (1992: 14), menyebut Alexander Pope, penyair inggris abad ke -17 pernah menulis dalam salah satu puisinya "Hope springs eternal in the human breast" yang berarti "harapan senantiasa bersemi abadi di dalam manusia" seperti harapan atau keinginan, dapat dikatakan bahwa ambisi pun bersemi abadi di dalam dada manusia, tetapi ada satu hal yang merangsang atau mendorong tumbuh suburnya ambisi tersebut seperti tanaman yang mempunyai potensi hidup namun butuh pupuk 
untuk menjadikanya tumbuh subur. Dapat dipahami dari pengertian tersebut ambisi sudah ada dalam diri manusia, tetapi kemunculan ambisi ini didorong oleh suatu faktor.

Faktor yang mendorong munculnya ambisi dari dalam diri seseorang dibagi menjadi dua, yaitu keadaan buruk dan keadaan baik, hal ini juga dijelaskan Widarso (1992: 14-17). Ada dua macam faktor yang dapat merangsang ambisi untuk tumbuh subur. Faktor yang pertama adalah keadaan buruk, baik di lingkungan keluarga seorang maupun di masyarakat sekitarnya. Keadaan buruk ini menantang seseorang untuk mengubah atau memperbaikinya. "mengubah" atau "memperbaiki" disini bersifat individual ataupun komunual.

Ambisi untuk mengubah atau memperbaiki diri sendiri (bersifat individual) dapat di temui pada diri seseorang yang terjepit dengan situasi yang tidak menguntungkan, ia akan berusaha dengan keras agar dapat mengubah situasi buruk tersebut. Dapat disimpulkan keadaan buruk itulah yang justru memupuk ambisinya. Widarso (1992: 15) menjelaskan salah satu contohnya ambisi seseorang yang tumbuh dikeluarga berkecukupan, namun keluarganya pernah memiliki aib sehingga ia sering mendapat cemooh dari teman-temannya. Orang tersebut bertekad untuk berprestasi dan berkarir dengan baik. ia menuntut ilmu dan mendalami apa yang menjadi minatnya hingga sukses mengejar cita-citanya bekerja dibidang yang diinginkan. Situasi menjepit membuat ia mempunyai ambisi dan benar-benar mencapai ambisinya.

Selain bersifat individual, Widarso (1992: 16) menjelaskan ambisi untuk mengubah atau memperbaiki dapat bersifat komunal atau mengubah atau memperbaiki masyarakat yaitu seseorang yang ambisinya tidak diarahkan pada dirinya sendiri. Misalnya seseorang disuatu tempat yang manyarakat linkungan tempat tinggalnya kurang peduli dengan sekitar, ia berusaha mengubah dan memperbaikinya dengan mengajak masyarakat tersebut berdiskusi, berbagi pikiran dan pengalaman. Usaha orang tersebut mebuat masyarakat lingkungannya menjadi lebih aktif dan peduli sekitar.

Faktor kedua yang dijelaskan Widarso (1992: 17), adalah keadaan baik, baik dalam diri seseorang maupun lingkungan sekitarnya. Maksudnya, keadaan baik itulah yang merangsangnya untuk meningkatkan diri menjadi lebih baik. Orang merasa kuat dan mampu biasanya ingin mencapai anak tangga yang teratas. Contohnya seseorang yang memiliki suatu kemampuan tertentu akan terus bekerja sampai ia mengungkapkan seluruh kemampuannya. Sehingga dapat disimpulkan ambisi itu tumbuh subur karena dipupuk dengan keadaan yang positif.

\section{Ambisi Negatif}

Ambisi dalam makna yang negatif bisa dikarenakan sikap mental yang negatif. Ambisi dalam diri manusia adalah baik, ambisi menjadi buruk karena menempel pada sikap mental yang buruk. Widarso (1992:21) mengemukakan ada empat sikap mental buruk yang berkaitan dengan ambisi yakni egoisme (selfishness), perfeksionisme (perfectionism), kecanduan kerja (workaholic), dan kepribadian tipe A (type A personality).

\section{a. Egoisme (Selfishness)}

Seseorang yang memiliki sifat egois tertarik hanya pada dirinya sendiri, orang tersebut tidak merasa senang jika memberi, tetapi hanya senang kalau mendapat. Orang dengan sifat tersebut juga sangat memperhatikan dirinya sendiri tetapi sebenarnya dia hanya melakukan suatu usaha yang sia-sia untuk menutupi dan mengompensasi kegagalanya dalam memperhatikan dirinya yang sejati. Jika ambisi itu menempel pada orang yang egois, ada kemungkinan orang tersebut tidak segan-segan mengeksploitasi atau menggunakan orang lain (take advantege of others) untuk memuaskan dirinya sendiri (Erich Fromm dalam Widarso, 1992: 21). Dapat disimpulkan bahwa yang buruk sebenarnya bukan ambisi itu sendiri melainkan egoismenya, oleh karena itulah ambisi memiliki pergeseran makna menjadi buruk.

Widarso (1992: 23) menjelaskan contoh sifat efois yang menempel pada ambisi, yaitu pada para mahasiswa yang berambisi ingin lulus. Para mahasiswa tersebut menipu seorang dosen baru yang akan mengawas ujian, mereka mengatakan bahwa dosen sebelumnya membiarkan mereka untuk mencontek. Ambisi para mahasiswa ingin lulus adalah baik namun, sifat egois membuat mereka menipu dosen baru 
demi kepentingan mereka sendiri tanpa merasa bersalah.

\section{b. Perfeksionisme (Perfectionism)}

Orang yang perfeksionis selalu menginginkan segala sesuatunya sempurna. Perfeksionisme didefinisikan oleh Tatenhove "the striving for the highest or the most perfect degree of a quality, trait, or accomplishement" yang berarti, perjuangan untuk mencapai posisi yang paling tinggi atau perjuangan ke arah tingkat kualitas, prilaku, dan prestasi yang paling sempurna (Tatenhove dalam Widarso, 1992: 24). Selanjutnya Widarso juga mengatakan perfeksionisme adalah bentuk paling tinggi dalam ambisi, dan tidak mungkin seseorang mencapai kesempurnaan selama hidup di dunia.

Salah satu contoh dari perfeksionis ini terlihat pada kasus Kapal Titanic tahun 1912, pembuat kapal tersebut mengatakan bahwa kapal Titanic adalah kapal besar yang canggih dan tidak akan tenggelam karna memiliki 16 ruang kedap air. Namun, yang terjadi kapal tersebut terkoyak dan tenggelam setelah menabrak bongkahan es besar dan menewaskan banyak penumpangnya. Hal tersebut mempelihatkan tidak ada suatu yang sempurna (Widarso, 1992: 25)

\section{c. Kecanduan Kerja (Workaholic)}

Istilah workaholic berasal dari work yang di padukan dengan alcoholic. Alcoholic adalah orang yang kecanduan minuman-minuman berakohol. Oates memadukan kata work dan alcoholic untuk menyebut orang yang kecanduan kerja, maka jadilah kata workoholic (Wayne Oates dalam Widarso, 1992: 24). Contoh yang dijelaskan Widarso (1992: 29) ialah seorang yang bekerja pada suatu lembaga Pendidikan dan membuka cabang dibanyak tempat. Hampir seluruh hidupnya diabdikan pada pekerjaannya, merasa senang dengan pekerjaan tanpa sadar ia adalah pecandu kerja, ia juga dapat diibaratkan seperti seseorang yang mengendarai mobil namun tidak menyadari bahwa ia melaju terlalu cepat.

Lebih lanjut Widarso menjelaskan empat motif mengapa seorang menjadi workaholic. Biasanya seseorang hanya "menyimpan" satu atau dua motif saja. Tetapi mungkin saja keempat motif itu ada pada dirinya.
Motif pertama yang diungkapkan Widarso ialah hasrat untuk menumpuk uang. Semakin banyak seseorang bekerja tentunya semakin banyak pula uang yang mengalir ke sakunya. Ini motif yang amat klasik dan paling mudah di deteksi. Motif kedua ialah hasrat menyamakan dirinya dengan the idealized self (citra diri yang didambakan/dilimpahkan). Motif yang ketiga, ketakutan menghadapi dirinya sendiri. Motif ketiga ini hampir sama dengan motif yang kedua, bedanya adalah pada motif kedua oarang mempunyai citra diri ideal yang di dambakan, sedangkan pada motif ketiga orang tidak suka pada citra dirinya yang sejati.

Motif terakhir yang diungkapkan Widarso
adalah ketidakmampuan menemukan aktualisasi diri (self actualization) yang tepat. Seorang ahli psikologi, Frank Bruno mendefinisikan aktualisai diri sebagai kecenderungan alami untuk memenfaatkan bakat dan potensi seseorang semaksimal mungkin (Frank Bruno dalam Widarso, 1992: 32). Orang yang tidak mampu menemukan bakat dan potensinya mungkin saja jatuh dalam "compulsive work" di bidang profesinya (Widarso, 1992: 29-32).

\section{d. Kepribadian Tipe A (Type A Personality)}

Widarso (1992: 33) menyebut dua ahli jantung dari rumah sakit dan pusat ilmu kedokteran Gunung Zion dan San Francisco, Mayer Friedman dan Ray Rosenman menemukan istilah Tipe A dan Tipe B untuk menyebut tipe-tipe kepribadian manusia. Dasar penggolongan tersebut adalah besarnya kemungkinan seseorang terkena penyakit jantung. Seseorang yang mempunyai kemungkinan besar untuk terserang penyakit jantung disebut dengan tipe A, sedangkan yang tidak disebut Tipe B. Orang yang bertipe A disebut mudah terkena penyakit jantung, karena orang-orang yang bertipe A mempunyai ciri-ciri agresif, kompetitif, tidak sabar atau selalu tergesa-gesa. Dapat disimpulkan, orang yang bertipe A ini selalu hidup dalam kungkungan stress. Mereka tidak mau orang menghalangi jalanya. Pikiranya hanya satu, yaitu cepat sampai pada tujuan.

Seseorang yang memiliki ambisi dan digolongkan bekepribadian Tipe A tidak mau orang lain menghalangi jalannya, ia ingin selalu menjadi nomor satu. Contohnya jika orang tersebut berada dalam sebuah diskusi, ia 
cenderung menguasai pembicaraan dan tidak sabar mendengarkan pendapat orang lain (Widarso, 1992: 33).

\section{METODE PENELITIAN}

Jenis penelitian yang akan digunakan dalam penelitian ini adalah penelitian kualitatif deskriptif. Menurut Danim penelitian kualitatif deskriptif yaitu data yang dikumpulkan berbentuk kata-kata, gambar, bukan angkaangka (2002: 51). Menurut Moleong (2004: 6), penelitian kualitatif adalah penelitian yang bermaksud untuk memahami fenomena tentang apa yang dialami oleh subjek penelitian misalnya perilaku, persepsi, motivasi, tindakan, dan lain-lain. Sementara itu, Moleong juga menjelaskan penelitian deskriptif adalah suatu bentuk penelitian yang ditujukan untuk mendeskripsikan atau menggambarkan fenomena-fenomena yang ada, baik fenomena alamiah maupun rekayasa manusia (2004: 17).

Adapun tujuan dari penelitian kualitatif deskriptif dalam penelitian ini adalah untuk menggambarkan penokohan dan ambisi dari tokoh Uchiha Itachi dalam anime Naruto Shippuden karya Masashi Kishimoto. Penokohan dan ambisi yang diteliti merupakan hasil dari memahami tindakan tokoh Uchiha Itachi dan disimpulkan dalam bentuk kata-kata.

Menurut Nazir (1988: 211) mendefiniskan bahwa pengumpulan data adalah prosedur yang sistematik dan standar untuk memperoleh data yang diperlukan. Selalu ada hubungan antara metode mengumpulkan data dengan masalah penelitian yang ingin dipecahkan. Masalah memberi arah dan mempengaruhi metode pengumpulan data. Pada penelitian ini menggunakan teknik simak dan teknik catat untuk mengumpulkan data.

Metode simak dilakukan untuk menyimak penggunaan bahasa. Istilah menyimak disini tidak hanya berkaitan dengan penggunaan bahasa secara lisan, tetapi juga penggunaan bahasa secara tertulis (Mahsun, 2005: 92). Metode ini memiliki teknik dasar yang berupa teknik sadap. Maksud teknik sadap disini adalah menyadap penggunaan bahasa, baik secara lisan maupun tulisan. Dalam praktiknya, teknik sadap ini diikuti dengan teknik lanjutan, yaitu teknik simak libat cakap, teknik simak bebas cakap, teknik simak bebas libat cakap, dan teknik catat (Mahsun, 2005: 93).

Metode simak dalam penelitian ini menggunakan teknik lanjutan berupa teknik catat. Teknik catat digunakan sebagai teknik dalam pengumpulan data. Teknik catat adalah mencatat beberapa bentuk yang relevan bagi penelitiannya dari penggunaan bahasa secara tertulis (Mahsun, 2005: 93).

Berikut teknik pengumpulan data oleh penulis.

a. Pengumpulan data dimulai dengan menyimak sumber data yaitu anime Naruto Shippuden karya Masashi Kishimoto berulang kali.

b. Penulis mencatat semua data seperti dialog, adegan dan unsur intrinsik yang berkaitan dengan tokoh dan ambisi tokoh Uchiha Itachi.

c. Mengumpulkan hasil catat yang dilakukan.

d. Memilah data yang dibutuhkan sesuai dengan pembahasan, dan selanjutnya akan dianalisis oleh penulis.

Sebuah penelitian membutuhkan suatu validasi data atau uji validitas agar data penelitian yang dihasilkan valid. Data yang valid adalah data "yang tidak berbeda" antara data yang dilaporkan oleh peneliti dengan data yang sesungguhnya terjadi pada obyek penelitian menurut Sugiyono (2006: 299). Azwar (1987: 173) menyatakan bahwa validitas berasal dari kata validity yang mempunyai arti sejauh mana ketepatan dan kecermatan suatu instrumen pengukur (tes) dalam melakukan fungsi ukurnya. Sedangkan menurut Sugiyono, validitas merupakan derajat ketepatan antara data yang terjadi pada obyek penelitian dengan daya yang dapat dilaporkan oleh peneliti (2006: 299).

Peneliti menerapkan konsep tersebut pada data dalam penelitian ini dengan menanyakan hasil transkrip sumber data berupa dialog kepada tiga validator agar didapatkan hasil data yang konsisten atau sama. Validator pertama yaitu peneliti, validator kedua ialah seseorang yang memiliki tingkat kemampuan Bahasa Jepang lebih tinggi, yaitu Nisa Rahmafira F. yang bersetifikasi N2 dan validator ketiga ialah seorang yang berbahasa utama Jepang atau berasal dari Jepang, Nakata Chiharu seorang mahasiswi Jepang. 


\section{HASIL PENELITIAN}

Pada bagian ini akan disajikan hasil penelitian dan pembahasan bagaimana penokohan dan ambisi tokoh Uchiha Itachi dalam anime Naruto Shippuden karya Masashi Kishimoto.

\section{Penokohan}

Mengenal penokohan tokoh dapat dibagi menjadi beberapa dimensi seperti yang diungkapkan Waluyo (2003: 14-19) penokohan tokoh yang digambarkan dalam tiga dimensi (watak dimensional). Penggambaran itu berdasarkan keadaan fisik, psikis, dan sosial (fisiologis, psikologis, dan sosiologis).

\section{a. Fisik}

Tokoh Uchiha Itachi memiliki keaadan fisik seperti berjenis kelamin laki-laki, berambut hitam lurus dan panjang, memiliki tubuh yang tinggi dan tegap, mengenakan jubah hitam bergambar awan merah, mengekan pelindung kepala desa Konoha yang terdapat goresan panjang yang membagi lambang ditengahnya. Keadaan fisik tersebut sesuai dengan penggambaran langsung karakterisasi penampilan dari pengarang melalui metode langsung (telling).

Ciri fisik lain tokoh Uchiha dengan karakterisasi penokohan melalui dialog dan disampaikan melalui pemaparan tidak langsung pengarang (showing) yaitu melalui dialog tokoh lain, Sasuke mengatakan jika mata Itachi masih sama, yaitu mata yang memiliki tatapan dingin.

\section{b. Psikis}

Tokoh Itachi dianggap criminal dan penghianat, kondisi psikis tokoh Itachi yaitu memiliki sikap yang tenang dan memiliki emosi yang stabil atau tidak mudah emosi. Selain itu tokoh Itachi memiliki sikap penyayang, sopan dan santun. Hal tersebut dipahami dari percakapan bersama ayah, ibu dan adik lakilakinya yang bernama Sasuke.

\section{c. Sosiologis}

Uchiha Itachi dalam kondisi sosialnya dapat dipahami tokoh Itachi merupakan bagian dari klan Uchiha dan menjadi bagian dari anbu. Tokoh Itachi bergabung dalam kelompok yang memiliki rencana untuk menangkap semua Jinchuuriki dan menyegel Bijuu bernama
Akatsuki. Hal ini dapat dipahami dari percakapan Itachi ketika berada pertama kali memasuki anbu dan Ketika sudah berada di Akatsuki.

\section{Ambisi}

\section{a. Ambisi}

Peneliti menganalisa bagaimana ambisi tokoh Itachi. Tokoh Itachi dimanfaatkan oleh petinggi desa. Itachi di tugaskan pada misi untuk membunuh seluruh klannya termasuk keluarganya sendiri. Tokoh Itachi rela membunuh klannya sendiri demi cintanya pada desanya. Kemudian Itachi mati dianggap kriminal dan penghianat, menerima cercaan dan dibenci yang seharusnya ia dihormati dan dicintai karena pengorbanannya. Itachi bahkan tersenyum saat mati. Hal tersebut menunjukan bagaimana tokoh Itachi rela dicerca dan dimaki demi melindungi desa.

Sebelum tokoh Itachi mati, ia menemui Naruto untuk menanyakan apa yang akan dilakukan jika Sasuke tidak mau menerima ajakannya untuk kembali ke desa Konoha dan justru berbalik menyerang desa. Itachi memastikan jika Naruto tetap akan membela desa tanpa harus membunuh Sasuke yang mudah terpengaruh. Peneliti memahami bagaimana tokoh Itachi yang masih dianggap kriminal dan penghianat desa tetap memastikan jika masih ada sesorang yang akan melindungi desa. Selain itu, tokoh Itachi meng memberikan sedikit kekuatannya kepada Naruto setelah Itachi memastikan Naruto yakin dengan katakatanya, setelahnya Itachi pergi tanpa perlawanan. Tokoh Itachi memberikan sedikit kekuatannya kepada Naruto yang yakin dengan kata-katanya untuk melindungi desa.

Tokoh Sasuke, adik dari tokoh Itachi baru saja mengetahui bagaimana Itachi berkorban banyak demi melindungi desa, namun Sasuke merasa bahwa setelah kedamaian yang dilindungin Itachi, petinggi desa membuangnya dan berniat menjadikan desa dan petingginya sebagai objek balas dendamnya. Peneliti memahami usaha Itachi untuk melindingi desa dan mengorbankan dirinya membuat adiknya memiliki dendam terhadap petinggi dan desa.

Setelah beberapa saat tokoh Itachi mati, tokoh Kabuto membangkitkan dan mengendalikan Itachi, kemudian ia bertemu kembali dengan Naruto dan membantu Naruto 
melawan tokoh lainnya setelah lepas dari kendali jutsu tersebut, Itachi yang mengetahui rencana balas dendam Sasuke menyerahkan dan mempercayakan masalah tersebut pada Naruto. Peneliti memahami bahwa tokoh Itachi mempercayakan Naruto untuk menghentikan Sasuke yang akan melakukan serangan ke desa.

Tokoh Itachi terlepas dari kendali tokoh Kabuto karena pengaruh kekuatan yang ia berikan kepada Naruto sebelumnya. Kekuatan tersebut berupa seekor gagak yang salah satu matanya dicangkok mata sharingan milik salah satu klan Uchiha bernama Uchiha Shisui. Uchiha Shisui dikenal sebagai pemilik kekuatan genjutsu terkuat, ia memiliki Teknik kotoamatsukami yang mampu mengendalikan seseorang tanpa disadari orang tersebut. Itachi sengaja menggunakan kekuatan tersebut untuk mempengaruhi seseorang untuk melindungi desa, namun kekuatan tersebut berhasil digunakan untuk dirinya sendiri.

Setelah berpisah dengan Naruto, tokoh Itachi berhasil mengalahkan tokoh Kabuto dan akan menghentikan jutsu Edo tensei. Jutsu Edo tensei ini adalah jutsu yang dapat menhidupkan dan mengendalikan seseorang yang telah meninggal, saat itu Kabuto menggunakan jutsu tersebut terhadap banyak ninja hebat yang telah meninggal. Salah satu ninja yang bangkitkan dan dikendalikan ialah Itachi sendiri, sehingga saat ia akan menghentikan jutsu tersebut, Itachi juga akan menghilang. Meskipun Itachi akan hilang, ia mengatakan bahwa ia dapat melindungi desa sekali lagi. Sebelum ia menghilang, setelah ia berhasil menghentikan jutsu Edo tensei, Itachi mengatakan jika ia telah menyampaikan semua kebenaran dan meminta maaf pada Sasuke karena tidak mengatakan yang sebenarnya terjadi sebelumnya bagaimana ia melindungi desa.

Sesuai kesimpulan peneliti dari definisi beberapa ahli yang telah diebutkan, ambisi dapat dimaknai sebagai dorongan atau motivasi seseorang disertai usaha atau perilaku untuk mencapai suatu tujuan yang telah dicitacitakannya. Tokoh Itachi memiliki tujuan untuk memepertahankan kedamaian Desa Konoha dengan usaha melindungi desa tersebut meskipun harus mengorbakan banyak hal seperti yang telah peneliti analisis.

\section{b. Faktor Pendorong}

Ambisi tokoh Itachi tersebut muncul karena didorong oleh beberapa faktor, yaitu kondisi baik dan kondisi buruk baik secara komunal dan individual. Kondisi buruk komunal yang sebagai situasi menjepit tokoh Itachi adalah peperangan, ketidakpercayaan, kecurigaan dan perlakuan terhadap klannya. Sedangkan kondisi buruk individual pada tokoh Itachi adalah perang yang menyebabkan trauma.

Tokoh Itachi yang mencitai kedamaian ialah kondisi baik individual bagi Itachi. Sedangkan kondisi baik komunal bagi tokoh Itachi ialah kedamaian yang ia rasakan saat itu. Kedua hal tersebutlah yang merangsang tokoh Itachi untuk meningkatkan kondisi baik tersebut yaitu melindungi dan mempertahankan kedamaian desa dengan semua usahanya.

\section{c. Ambisi Negatif}

Ambisi dalam makna yang negatif bisa dikarenakan sikap mental yang negatif. Ambisi dalam diri manusia adalah baik, ambisi menjadi buruk karena menempel pada sikap mental yang buruk yaitu yakni egoisme (selfishness); perfeksionisme (perfectionism); kecanduan kerja (workaholic); kepribadian tipe A (type A personality).

Sikap mental buruk pertama yaitu egoisme tidak menempel pada tokoh Itachi. Tokoh Itachi bukanlah seseorang yang hanya hanya senang kalau mendapat. Tokoh Itachi juga bukanlah seseorang yang hanya memperhatikan dirinya sendiri, ia mementingkan orang lain diatas kepentingannya, ia juga melakukan usaha yang besar untuk orang lain bahkan mengorbankan dirinya sendiri. Selain itu, peneliti juga memahami tokoh Itachi tidak mengeksploitasi atau menggunakan orang lain untuk memuaskan dirinya sendiri.

Tokoh Itachi memiliki sikap atau mental perfeksionis, disimpulkan dari bagaimana Itachi yang dapat berpikir panjang dan merencanakan sesuatu dengan baik sehingga apa yang menjadi rencananya akan terjadi. Hal tersebut menunjukan adanya usaha agar rencana atau keinginannya sempurna. Peneliti juga memahami bahwa tokoh Itachi menjalakan rencana yang ia pikir sudah sempurna untuk melindungi Konohan dan Klan Uchiha, hal tersebut membuktikan ia seorang yang perfeksionis. Meskipun misi yang tokoh Itachi 
jalankan melindungi kedamaian desa Konoha dari serangan kudeta Klan Uchiha, tetapi ia harus mengorbankan keluarga dan anggota klannya serta membuat tokoh Sasuke berbalik membenci Konoha.

Tokoh Itachi yang memiliki percaya diri bahwa Itachi merupakan ninja yang kuat dan tidak terkalahkan menunjukan salah satu motif dalam kecanduan kerja yaitu menyamakan dirinya dengan the idealized self (citra diri yang didambakan/dilimpahkan) yaitu salah satu motif pada sikap mental kecanduan kerja pada tokoh Itachi.

Sikap tenang Itachi dalam menghadapi dan menganalisis serangan lawan menunjukan jika ia bukanlah orang yang mempunyai ciri-ciri agresif, kompetitif, tidak sabar atau selalu tergesa-gesa menunjukan tokoh Itachi memiliki kepribadian tipe $\mathrm{B}$ atau tidak mudah terkena penyakit jantung meskipun ia memiliki ambisi.

Tokoh Itachi memiliki dua sikap mental buruk yang biasanya melekat pada sesorang yang berambisi yaitu perfeksionis dan salah satu motif kecanduan kerja, meskipun Itachi berambisi melindungi kedamaian desa Konoha dari serangan kudeta Klan Uchiha, tetapi ia harus mengorbankan keluarga dan anggota klannya serta membuat tokoh Sasuke berbalik membenci Konoha dikarenakan sikap mental buruk yang telah disebutkan.

\section{Kesimpulan}

Berdasarkan hasil analisis tentang penokohan dan ambisi tokoh Uchiha Itachi dari anime Naruto Shippuden karya Masashi Kishimoto, dapat disimpulkan tokoh Uchiha Itachi memiliki ciri fisik berjenis kelamin lakilaki, berambut hitam lurus dan panjang, memiliki tubuh yang tinggi dan tegap, mengenakan jubah hitam bergambar awan merah, mengekan pelindung kepala desa Konoha yang terdapat goresan panjang yang membagi lambang ditengahnya. Selain itu, Itachi juga memiliki tatapan yang dingin. Meskipun tokoh Itachi dianggap kriminal dan penghianat, kondisi psikis tokoh Itachi yaitu memiliki sikap yang tenang dan memiliki emosi yang stabil atau tidak mudah emosi. Selain itu tokoh Itachi memiliki sikap penyayang, sopan dan santun. Uchiha Itachi dalam kondisi sosialnya dapat dipahami tokoh Itachi merupakan bagian dari klan Uchiha dan menjadi bagian dari anbu. Tokoh Itachi bergabung dalam kelompok yang memiliki rencana untuk menangkap semua Jinchuuriki dan menyegel Bijuu.

Tokoh Itachi memiliki tujuan untuk memepertahankan kedamaian Desa Konoha dengan usaha melindungi desa tersebut meskipun harus mengorbakan dirinya sendiri dan klannya. Ambisi tokoh Itachi tersebut muncul karena didorong oleh beberapa faktor, yaitu kondisi baik dan kondisi buruk baik secara komunal dan individual. Kedua hal tersebutlah yang merangsang tokoh Itachi untuk meningkatkan kondisi baik tersebut yaitu melindungi dan mempertahankan kedamaian desa dengan semua usahanya.

Tokoh Itachi memiliki dua sikap mental buruk yang biasanya melekat pada sesorang yang berambisi yaitu perfeksionis dan salah satu motif kecanduan kerja, meskipun Itachi berambisi melindungi kedamaian desa Konoha dari serangan kudeta Klan Uchiha, tetapi ia harus mengorbankan keluarga dan anggota klannya serta membuat tokoh Sasuke berbalik membenci Konoha dikarenakan sikap mental buruk yang telah disebutkan.

\section{Saran}

Setelah melakukan analisis penokohan dan ambisi tokoh Uchiha Itachi, maka saran yang dapat peneliti sampaikan adalah sebagai berikut.

1. Penelitian terhadap tokoh Uchiha Itachi dalam anime Naruto Shippuden adalah salah satu penelitian dari bagian kecil dari unsur-unsur pembangun karya sastra. Hal ini dapat dijadikan peluang bagi peneliti lain untuk menganalisis lebih jauh unsur-unsur karya sastra lainnya baik melalui tokoh dan anime yang sama atau lainnya.

2. Anime Naruto Shippuden karya Masashi Kishimoto dapat dijadikan peluang bagi peneliti khususnya yang mengkaji tokoh atau karakter karena memiliki banyak tokoh yang dapat menjadi subjek penelitian

3. Penelitian ambisi tokoh dari suatu karya sastra masih belum banyak yang dapat peneliti temukan, penelitian ini dapat menjadi salah satu referensi bagi peneliti yang akan meneliti ambisi suatu tokoh 


\section{Daftar Pustaka}

Alex Sobur. 2004. Semiotika Komunikasi. Bandung: Remaja Rosdakarya.

Aminuddin, 2004. Pengantar Apresiasi Karya Sastra. Bandung: Sinar Baru. Algensindo

Azwar, Saifuddin. 1988. Sikap Manusia Teori dan Pengukurannya. Yogyakarta: Liberty

Danim, Sudarwan, 2002. Menjadi Peneliti Kualitatif Rancangan Metodologi, Presentasi, dan Publikasi Hasil Penelitian untuk Mahasiswa dan Penelitian Pemula Bidang Ilmu Sosial, Pendidikan, dan Humaniora. Bandung: Remaja Rosdakarya.

Mahsun. 2005. Metode Penelitian Bahasa. Jakarta: PT Raja Grafindo Persada

Marliah, Siti. 2016. "Karakterisasi Tokoh Utama

Dalam Kumpulan Cerpen Celeng

Satu Celeng Semua Karya Triyanto Triwikromo Dan Pembelajarannya di

SMA", Skripsi, Fakultas Keguruan Dan Ilmu Pendidikan Universitas Lampung.

Minderop, Albertine. 2005. Metode Karakterisasi Telaah Fiksi. Jakarta: Yayasan Obor Indonesia.

Moleong, Lexy J. 2010. Metodologi Penelitian Kualitatif. Bandung: Remaja Rosdakarya.
Nazir, Mohammad. 1988. Metode Penelitian, Jakarta: Ghalia Indonesia,

Nurgiyantoro, Burhan. 2002. Teori Pengkajian Fiksi. Yogyakarta: Gajah Mada

University Press.

Nurgiyantoro, Burhan. 2005. Sastra Anak: Pengantar Pemahaman Dunia Anak.

Press.

Yogyakarta: Gajah Mada University

Nurgiyantoro, Burhan. 2007. Teori Pengkajian Fiksi. Yogyakarta: Gadjah Mada.

Sayuti, A. Suminto. 2000. Berkenalan dengan Prosa Fiksi. Yogyakarta: Gama Media.

Sugiyono. 2006. Metode Penelitian Kuantitatif, Kualitatif, dan $\mathrm{R}$ \& $\mathrm{D}$. Bandung: Alfabeta.

Susanti, Susi. 2017. "Struktur Sastra Pada Film Rudi Habibie". Dalam Jurnal Diksastrasia.

Volume1, No 2.

Waluyo, Herman J. 2003. Drama: Teori dan Pengajarannya. Yogyakarta: Hanindita

Graha Widy. Budianta). Jakarta:

Gramedia.

Widarso, Wishnubroto. 1992. Ambisi: kawan atau lawan. Yogyakarta: Kanisius. 